\title{
SUPEROXIDE DISMUTASE 1 AND 2 GENE POLYMORPHISM IN TURKISH VITILIGO PATIENTS
}

\author{
Tuna $\mathrm{A}^{1}$, Ozturk $\mathrm{G}^{1}$, Gerceker $\mathrm{TB}^{1}$, Karaca $\mathrm{E}^{2, *}$, Onay $\mathrm{H}^{2}$, Guvenc $\mathrm{SM}^{2}$, Cogulu $\mathrm{O}^{2}$
}

\begin{abstract}
*Corresponding Author: Emin Karaca, M.D., Associacte Professor, Department of Dermatology and Venerology, Faculty of Medicine, Ege University, Kazım Dirik mah, Izmir, Turkey. Tel: +90-232-3903961-+90-532-2579285. Fax: +90-2323903971. E-mail: karacaemin@gmail.com
\end{abstract}

\begin{abstract}
Vitiligo is an acquired disease of unknown etiology. Several theories have been proposed to understand the pathogenesis. The role of oxidative stress has been getting more important in recent years. One of the primary antioxidant enzymes in vitiligo is the superoxide dismutase (SOD). The aim of this study is to investigate the polymorphisms of the SOD1 and SOD2 in Turkish vitiligo patients. One hundred one vitiligo patients and 99 healthy controls without family history of vitiligo were included into the study. The SOD1 $35 \mathrm{~A} / \mathrm{C}$ and SOD2 A16V (C/T) polymorphisms were analyzed by polymerase chain reactionrestriction fragment length polymorphim (PCR-RFLP). Viti-ligo patients and control group of SOD1 $35 \mathrm{~A} / \mathrm{C}$ and $\mathrm{SOD} 2 \mathrm{~A} 16 \mathrm{~V}(\mathrm{C} / \mathrm{T})$ polymorphism allele frequencies were compared by using $\chi^{2}$ tests. The distribution of the SOD 1 35 AA and AC genotypes were similar in vitiligo patients and control group. When the patient and the control groups were compared for the SOD2 Ala9Val (C/T) polymorphism, a significant difference was determined for the distribution of the genotypes $[p=0.047$, odds ratio $(\mathrm{OR})=$ $2.075,95 \%$ confidence interval $(95 \% \mathrm{CI})=1.008-4.272]$. The relative risk for development of vitiligo was found as a 2-fold increase in the TT genotype. The increase of TT homozygosity in the vitiligo cases creates the problem on the transfer of the enzyme to the mitochondria and thus, the
\end{abstract}

\footnotetext{
${ }^{1}$ Department of Dermatology and Venerology, Faculty of Medicine, Ege University, Izmir, Turkey

${ }^{2}$ Department of Genetics, Faculty of Medicine, Ege University, Izmir, Turkey
}

SODs antioxidant effect may decrease in vitiligo but the polymorphism was not determined in all patients, so this study needs to be substantiated by other studies containing a higher number of patients.

Keywords: SOD1; SOD2; Superoxide dismutase (SOD); Vitiligo.

\section{INTRODUCTION}

Vitiligo, characterized by milky-white patches on the skin, is an acquired disease of unknown etiology. Histologically speaking, it is caused by a loss of melanocytes [1]. Several theories have been proposed to explain the pathogenesis; these include the autoimmune, the neural and the theory of self-destruction. Most current studies have focused on the genetic etiology, with genes related to the autoimmunity, melanin, and the biological reply process to the oxidative stress, being the most thoroughly investigated [2-6].

With regard to the pathogenic role of oxidative stress in vitiligo, the previous studies were directed toward changes in antioxidant enzyme activity in the blood and tissue. Although some conflicting results were attained, all studies did point to an impact of oxidative stress on vitiligo [7-12]. Superoxide dismutase (SOD), one of the primary antioxidant enzymes, was previously studied in relation to vitiligo and to date, three isoforms of SOD have been identified in humans. They are coded by three different genes: copper-zinc SOD (CuZn-SOD), manganese SOD (Mn-SOD), and extracellular SOD. The diversity in their form stems from amino acid alignment, active metal zone and their intra cell location. Copper-zinc SOD, defined as 
SOD1, is a cytosolic enzyme, Mn-SOD, namely SOD2, exists in the mitochondria; while the expression of the SOD3 enzyme, is limited to only plasma, lymphoid tissue or cerebrospinal liquids $[13,14]$.

Variations of SOD1 have previously been studied in relation to several clinical manifestations including amyo-trophic lateral sclerosis (ALS) and diabetes mellitus (DM) [15-17]. However, to the best of our knowledge, no studies considering associations between either gene polymorphism SOD1 $35 \mathrm{~A} / \mathrm{C}$ (rs2234694) or SOD2 $\mathrm{A} 16 \mathrm{~V}(\mathrm{C} / \mathrm{T})(\mathrm{rs} 4880)$ and vitiligo is currently available in the literature. The aim of this study was to investigate the polymorphisms of the SOD1 and SOD2 and their impact on Turkish vitiligo patients.

\section{MATERIALS AND METHODS}

Patients. The study included 101 vitiligo patients, with a control group of 99 . The diagnosis of vitiligo was based on clinical findings and the Wood lamp examination, while a vitiligo-free family history, and adequate general health, qualified probands for the control group. Types and volumes of vitiligo in relation to the study group are summarized in Table 1 (focal, segmental, acrofacial, generalized universal and mixed). Other factors, such as disease duration, family history and comorbidities including DM or Hashimoto's thyroiditis were also noted. Written informed consent was obtained from all subjects. The study was approved by the Ethics Committee of Ege University Medical Faculty, Izmir, Turkey.

DNA Isolation and Genetic Analyses. Two milliters of peripheral blood were extracted from each participant, collected into EDTA tubes and stored at $-20^{\circ} \mathrm{C}$. Genomic DNA was then isolated from the peripheral blood using standard techniques (DNA Isolation Blood Mini Kit; Invitek, Berlin, Germany).

PCR-RFLPAnalyses. For the polymorphism analysis of SOD1 $35 \mathrm{~A} / \mathrm{C}$ and SOD2 A16V (C/T), polymerase chain reaction-restriction fragment length polymorphim (PCR-RFLP) was performed on both occasions. For SOD1 gene $35 \mathrm{~A} / \mathrm{C}$ polymorphism, PCR was initiated using forward (5'-CTA TCC AGA AAA CAC GGT GGG CC-3') and reverse (5'-TCT ATA TTC AAT CAAATG CTA CAA AAC-3') primers. For SOD2 gene A16V (C/T) polymorphism, forward (5'-AGC AGG CAG CTG GCG CCG G-3') and reverse (5'-GCG TTG ATG TGA GGT TCC AG$3^{\prime}$ ) primers were used. A total volume of $25 \mu \mathrm{L}$, containing $50 \mathrm{ng}$ DNA, $2 \mathrm{mM}$ dNTPs, $2 \mathrm{nmol}$ of each related primer, $1.5 \mathrm{mM} \mathrm{MgCl} 2$ and $3 \mathrm{U}$ Taq polymerase, was used in each polymorphism PCR set up. Each PCR cycle consisted of denaturation at $94{ }^{\circ} \mathrm{C}$ for 30 seconds, extension at $72{ }^{\circ} \mathrm{C}$ for 30 seconds, and a final extension step of incubation at $72{ }^{\circ} \mathrm{C}$ for $7 \mathrm{~min}$. Annealing temperatures were $55^{\circ} \mathrm{C}$ and $59.6^{\circ} \mathrm{C}$ for 30 seconds for SOD1 $35 \mathrm{~A} / \mathrm{C}$ and SOD2 $\mathrm{A} 16 \mathrm{~V}(\mathrm{C} / \mathrm{T})$ polymorphisms, respectively.

Genotyping of the SOD1 Gene $35 \mathrm{~A} / \mathrm{C}$ Polymorphism. The $278 \mathrm{bp}$ PCR products for the SOD1 gene 35 $\mathrm{A} / \mathrm{C}$ polymorphism were digested using the restriction enzyme HhaI (Fermentas, The Thermo Fisher Scientific, Waltham, MA, USA) at $37{ }^{\circ} \mathrm{C}$ for 3 hours with $5 \mathrm{U}$ enzymes. The presence of the $35 \mathrm{C}$ mutant allele manifested through the appearance of sites of restriction. Following enzyme digestion, products were then cut into two fragments of 207 and 71 bp (Figure 1).

Genotyping of the SOD2 Gene A16V (C/T) Polymorphism. A 267 bp amplicon of the SOD2 gene A16V (C/T) polymorphism was digested using NgoMIV (Fermentas) restriction endonuclease, left overnight at $37{ }^{\circ} \mathrm{C}$. Due to the presence of a mutant allele, the $267 \mathrm{bp} \mathrm{PCR}$ amplification product digested into fragments of 183 and $84 \mathrm{bp}$, respectively (Figure 1). All fragments were visualized via electrophoresis on $4.0 \%$ agarose gel after restriction. Positive and negative controls were used in each genotyping assay.

Sequencing of the PCR Amplified Product. As a safeguard, Sanger sequencing of the PCR product was used to confirm the presence of the SOD1 and SOD2 gene sequences before continuing (Figure 2).

Statistical Analyses. The SOD1 $35 \mathrm{~A} / \mathrm{C}$ and SOD2 A16V $(\mathrm{C} / \mathrm{T})$ polymorphism allele frequencies of Vitiligo patients were compared to those of a control group using

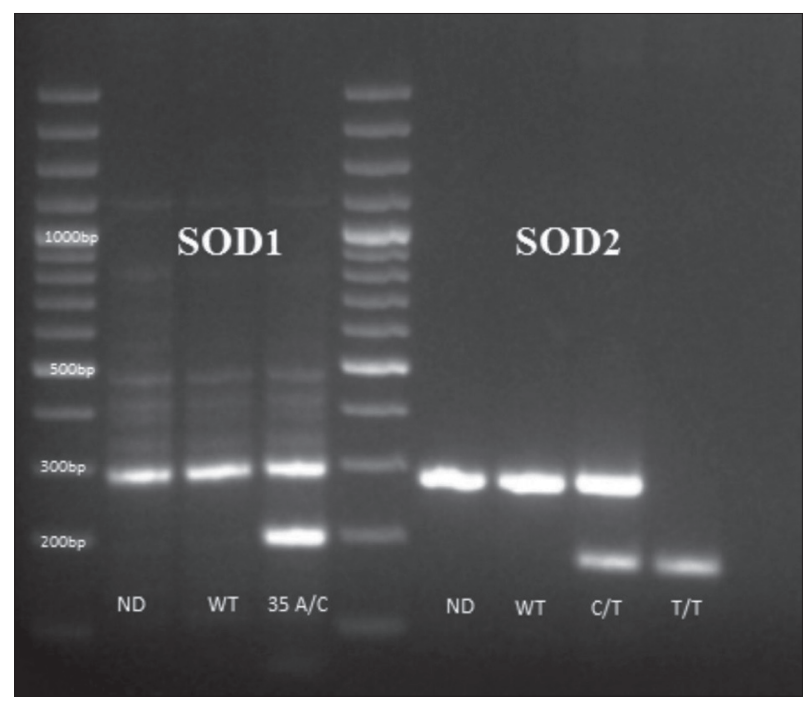

Figure 1. Gel images of each genotype along with DNA ladder (100 bp plus). 


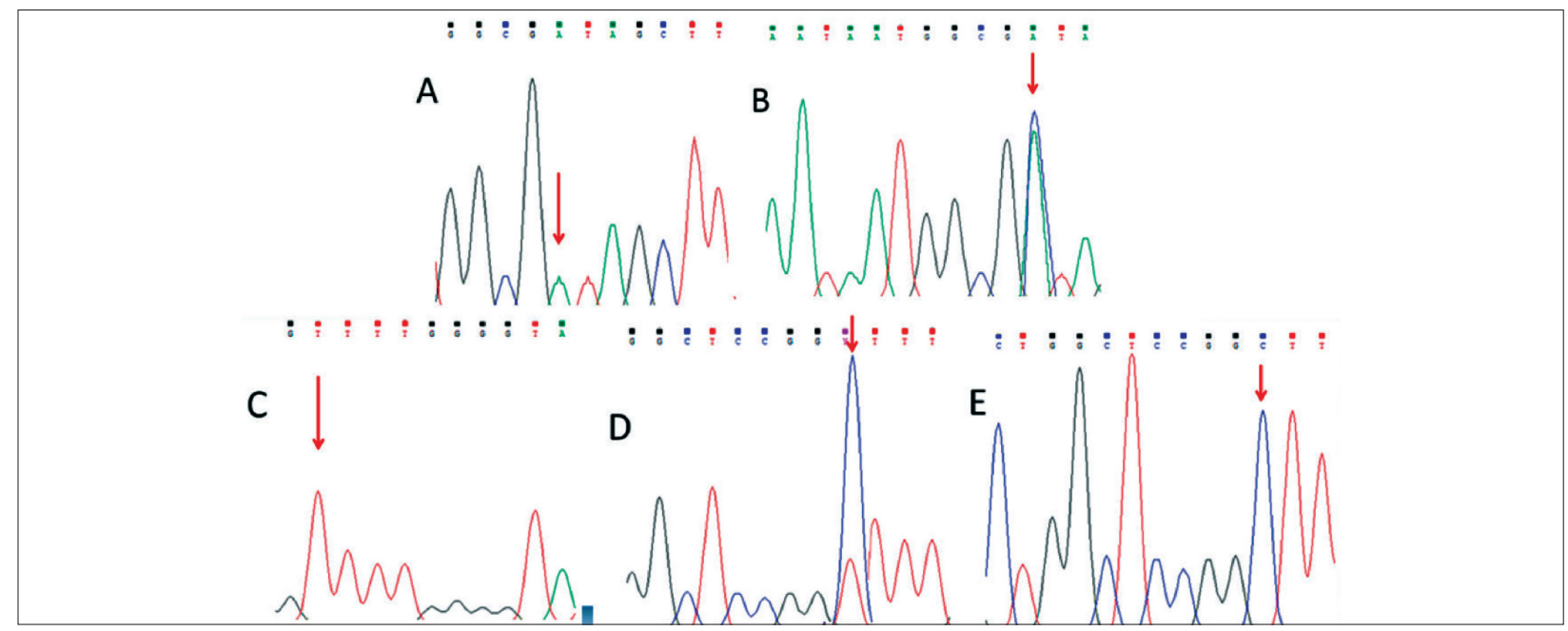

Figure 2. The sequencing chromatogram of SOD1 $35 \mathrm{~A} / \mathrm{C}$ and SOD2 Ala9Val (C/T) polymorphisms. A) SOD1 35 AA wild type; B) SOD1 35 AC heterozygotes; C) SOD2 Ala9Val TT wild type; D) SOD2 Ala9Val TC heterozygotes; E) SOD2 Ala9Val CC homozygotes.

the $\chi^{2}$ test; the application of statistical program SPSS 9.0.p Values of $<0.05$ (one-way) were considered to be significant.

\section{RESULTS}

A total of 101 vitiligo patients; 58 women, (57.4\%) and 43 men (42.6\%) were enrolled in the study. The mean age was $37.4 \pm 15.2$; range $7-68$ years. The control group consisted of 99 healthy volunteers; 50 women $(50.5 \%)$ and 49 men $(49.5 \%$ ), with a mean age of $36.6 \pm 12.6$, range 18-69. In terms of age and gender, no statistical difference existed between the groups.

The median duration of vitiligo was 9.0 years (range 1-35 years). A family history of vitiligo was noted in firstdegree relatives of 23 patients $(22.7 \%)$.

With regard to vitiligo type, 46 patients were focal (45.5\%), 25 acrofacial (24.7\%), 21 generalized (20.7\%), four segmental (3.9\%), three universal $(2.9 \%)$ and two pa- tients were classified as mixed (1.9\%). Results can be seen in Table 1. The comorbidities in vitiligo patients were as follows: Hashimoto's thyroiditis 12 patients (11.8\%), DM 11 patients $(10.8 \%)$, pernicious anemia two patients $(1.9 \%)$. When considering the distribution of the comor-bidities between the vitiligo and the control group ( $p=0.431)$, no statistical difference was revealed. Similarly, when genotypes of SOD1 $35 \mathrm{AA}$ and AC were compared between groups (Table 2), the distribution rate was considered insignificant. There was no statistical difference for genotype and allele frequency between the groups ( $p=0.21$ ) (Table 3).

However, when the patient cohort and control group were compared for the presence of the SOD2 Ala9Val $(\mathrm{C} / \mathrm{T})$ polymorphism, the distribution of the genotypes $[p$ $=0.047$, odds ratio $(\mathrm{OR})=2.075,95 \%$ confidence interval $(95 \% \mathrm{CI})=1.008-4.272]$ was considered significant. The genotype distribution in vitiligo and the control group was as follows: CC $25.7 \%$, CT $36.6 \%$, TT $37.6 \%$; CC 35.3\%, CT $40.4 \%$, TT $24.2 \%$ ) (Table 2). In the TT genotype, rela-

Table 1. Demographic and clinical parameters of vitiligo patients. (Values are presented as mean.)

\begin{tabular}{|l|c|c|c|c|c|c|c|}
\hline Clinical Type & \multicolumn{2}{|c|}{$n$} & \multicolumn{3}{c|}{ Gender } & \multicolumn{2}{c|}{ Age } \\
\hline & $n$ & $\%$ & $\begin{array}{c}\mathrm{F} \\
n(\%)\end{array}$ & $\begin{array}{c}\mathrm{M} \\
n(\%)\end{array}$ & $\begin{array}{c}\mathrm{F} \\
n(\%)\end{array}$ & $n(\%)$ & 22 \\
\hline Focal & 46 & 45.55 & 25 & 24.76 & 11.78 & $35.62 ; \mathrm{F}: 32.16 ; \mathrm{M}: 39.39$ \\
\hline Acrofacial & 25 & 24.75 & 13 & 12.87 & 10.89 & $32.15 ; \mathrm{F}: 31.26 ; \mathrm{M}: 33.42$ \\
\hline Generalized & 21 & 20.79 & 13 & 12.87 & 8 & 7.92 & $38.78 ; \mathrm{F}: 41.34 ; \mathrm{M}: 34.62$ \\
\hline Segmental & 4 & 3.96 & 2 & 1.98 & 2 & 1.98 & $27.35 ; \mathrm{F}: 27.50 ; \mathrm{M}: 27.20$ \\
\hline Universal & 3 & 2.97 & 3 & 2.97 & - & - & 37.56 \\
\hline Mixed & 2 & 1.98 & 2 & 1.98 & - & - & 36.15 \\
\hline Total & 101 & 100.00 & 58 & 57.43 & 43 & 43.57 & \\
\hline
\end{tabular}

F: females; M: males. 
Table 2. The genotype and allele distribution in the patient and control groups for the SOD1 35 A/C SOD2 Ala-9Val (C/T) polymorphism.

\begin{tabular}{|c|c|c|c|c|c|c|c|}
\hline & Genotype & \multicolumn{2}{|c|}{ Patient $n \%$} & \multicolumn{2}{|c|}{ Control $n \%$} & Total & $p$ Value \\
\hline SOD1 & $\begin{array}{c}\text { AA } \\
\text { CA } \\
\text { CC } \\
\text { Total }\end{array}$ & $\begin{array}{r}96 \\
5 \\
0 \\
101\end{array}$ & $\begin{array}{r}96.05 \\
4.95 \\
0.00 \\
100.00\end{array}$ & $\begin{array}{r}97 \\
2 \\
0 \\
99\end{array}$ & $\begin{array}{r}97.98 \\
2.02 \\
0.00 \\
100.00\end{array}$ & $\begin{array}{r}193 \\
7 \\
0 \\
200\end{array}$ & 0.277 \\
\hline $35 \mathrm{~A} / \mathrm{C}$ & $\begin{array}{c}\text { A } \\
\text { C } \\
\text { Total }\end{array}$ & $\begin{array}{r}197 \\
5 \\
202\end{array}$ & $\begin{array}{r}97.52 \\
2.48 \\
100.00\end{array}$ & $\begin{array}{r}196 \\
2 \\
198\end{array}$ & $\begin{array}{r}98.98 \\
1.02 \\
100.00\end{array}$ & $\begin{array}{r}393 \\
7 \\
400\end{array}$ & 0.214 \\
\hline SOD2 & $\begin{array}{c}\text { CC } \\
\text { CT } \\
\text { TT } \\
\text { Total } \\
\end{array}$ & $\begin{array}{r}26 \\
37 \\
38 \\
101 \\
\end{array}$ & $\begin{array}{r}25.70 \\
36.60 \\
37.60 \\
100.00 \\
\end{array}$ & $\begin{array}{l}35 \\
40 \\
24 \\
99\end{array}$ & $\begin{array}{c}35.36 \\
40.40 \\
24.24 \\
100.00\end{array}$ & $\begin{array}{r}61 \\
77 \\
62 \\
200 \\
\end{array}$ & 0.047 \\
\hline Ala9Val (C/T) & $\begin{array}{c}\mathrm{T} \\
\mathrm{C} \\
\text { Total }\end{array}$ & $\begin{array}{c}154 \\
48 \\
202\end{array}$ & $\begin{array}{r}76.24 \\
23.76 \\
100.00\end{array}$ & $\begin{array}{r}124 \\
74 \\
198\end{array}$ & $\begin{array}{c}62.63 \\
37.37 \\
100.00\end{array}$ & $\begin{array}{l}278 \\
122 \\
400\end{array}$ & 0.460 \\
\hline
\end{tabular}

a Patients HWE: 0.0101, $p=0.9199$; control HWE: 0.0664, $p=0.7966$ (SOD1).

${ }^{\mathrm{b}}$ Patients HWE: $2.5320, p=0.1116$; control HWE: $5.7681, p=0.0163$ (SOD2).

Table 3: Distributions of SOD1 $35 \mathrm{~A} / \mathrm{C}$ and SOD2 Ala9Val (C/T) polymorphisms in cases and controls and risk of vitiligo.

\begin{tabular}{|c|c|c|c|c|}
\hline & Genotype/Allele & OR & $95 \% \mathrm{CI}$ & $p$ Value \\
\hline SOD1 & $\begin{array}{l}\text { AA } \\
\text { AC } \\
\text { A } \\
\text { C }\end{array}$ & $\begin{array}{l}1 \\
0.380 \\
0.688 \\
-\end{array}$ & $\begin{array}{l}- \\
0.072-2.005 \\
0.426-1.110 \\
-\end{array}$ & $\begin{array}{l}- \\
0.271 \\
0.281 \\
-\end{array}$ \\
\hline SOD2 & $\begin{array}{l}\text { CC } \\
\text { CT } \\
\text { TT } \\
\text { C } \\
\text { T }\end{array}$ & $\begin{array}{l}1 \\
1.750 \\
2.158 \\
0.792\end{array}$ & $\begin{array}{l}- \\
0.889-3.446 \\
1.044-4.462 \\
0.648-0.968\end{array}$ & $\begin{array}{l}- \\
0.105 \\
0.038^{\mathrm{a}} \\
0.022^{\mathrm{a}}\end{array}$ \\
\hline
\end{tabular}

${ }^{a}$ This is a statistically significant $p$ value.

tive risk for the development of vitiligo was found to have increased 2-fold. The T allelic frequency was determined as $76.2 \%$ in the patient cohort, with $62.67 \%$ for the control group, while $\mathrm{C}$ allelic frequency was $23.8 \%$ in the patients compared to $37.4 \%$ for the control group. There was no significant difference for allele frequency ( $p=$ 0.46) (Table 2).

More common alleles of both polymorphisms were considered as reference alleles. Logistic regression analysis showed no significant association between SOD1 35 A/C polymorphism (AA vs. $\mathrm{AC}: \mathrm{OR}=0.380,95 \% \mathrm{CI}$ : $0.072-2.005, p=0.271)$ and SOD2 Ala9Val $(\mathrm{C} / \mathrm{T})$ polymorphism (CC vs. CT: OR $=1.75,95 \%$ CI: 0.889-3.446, $p$ $=0.106)$. However, a significant association between cases and controls in the SOD2 Ala9Val $(\mathrm{C} / \mathrm{T})$ polymorphism (CC vs. TT: $\mathrm{OR}=2.158,95 \%$ CI: $1.044-4.462, p=0.038)$ (Table 3) was seen. Analysis also confirmed that the presence of the T allele of SOD2 Ala9Val (C/T) polymorphism increased the risk of vitiligo significantly $(\mathrm{OR}=0.792$, 95\% CI: 0.648-0.968, $p=0.022$ ) (Table 3).

\section{DISCUSSION}

The SOD enzymes together with glutathione peroxidase and catalase play a critical role, assuring the cell protection against free radicals. These enzymes contain redox metals in the centers of their catalytic zones that transform superoxide radicals to hydrogen peroxide and oxygen [14-18].

Oxidative stress can trigger a reaction that causes melanocytes destruction. Thus, the lesions of vitiligo may be brought on by psychological stress or physical events. The trauma and stress cause a catecholamine release, which results in vasoconstriction and hypoxia. Following cellular hypoxia and reoxygenation there is an increase in free oxygen 
radicals and toxic materials. In a study on malondialdehyde (MDA), level, SOD and glutathione peroxidase activity in the tissues of 114 vitiligo patients, Yildirim et al. [10] found tissue SOD activity of the patients was significantly higher than the control group. It was considered that the increased SOD activity observed in that study was caused by a reactive increase against excessive superoxide anion production [10].

This is the first study to evaluate the relationship between the SOD1 and SOD2 polymorphisms and vitiligo. In terms of the SOD2 Ala-9Val $(\mathrm{C} / \mathrm{T})$, the TT genotype frequency in the patient group was statistically and significantly higher than the control group. We observed a 2-fold relative risk increase for the development of vitiligo in subjects with the TT genotype. Thus, while not conclusive, our results do suggest that the SOD2 polymorphism might play a role in vitiligo.

In the literature, studies of the CuZn-SOD, described as the SOD1 enzyme, found the frequency of the Ala4Val mutation in SOD1 to be significantly higher than other mutations $[5,19,20]$. In our study, when we compared the distribution of genotype for the SOD1 $35 \mathrm{~A} / \mathrm{C}$ polymorphism, no significant diversity could be determined ( $p=$ 0.277 ). Likewise, when we compared groups, focusing on the SOD1 $35 \mathrm{~A} / \mathrm{C}$ polymorphism allele distribution, no significant diversity could be determined either $(p=0.214)$.

The SOD1 enzyme is cytosolic, and the antioxidant reactions occur in the mitochondria. This might explain the similarity of genotype and allele frequencies in both the cohort and control group.

The SOD2 enzyme, also known as Mn-SOD, has been studied more extensively than SOD1 due to the fact it is mitochondrial and inducible. The production of this particular enzyme rises via transcription in conjunction with a rise of the superoxide production. Two polymorphic structures have been determined for the SOD2 gene: Ala9 Val polymorphisms that is the I1e58Thr polymorphism occurring in the 339th nucleotide via the transformation of $\mathrm{C}$ to $\mathrm{T}$, and the Ala-9Val polymorphism that occurs in the 1183th nucleotide, again via the transformation of $\mathrm{C}$ to T. The Ile58Thr polymorphism reduces the enzymatic activity. The Ala/Val change occurs in the protein's mitochondrial target series where it causes greater problems than those associated with the enzyme activity during the transfer of enzymes to the mitochondria [14]. Sutton et al. [21] showed that the SOD2 alanine amino acid in liver of rats is more active than the valine amino acid. In this study, results have indicated that the increase in TT homozygosity in vitiligo cases causes problems during the transfer of enzymes to the mitochondria. This is followed by a decrease in the SOD2s antioxidant effect.
The Ala-9Val polymorphism has been studied in relation to Parkinson's disease, schizophrenia, urolithiasis, adult-onset obesity, motor neuron disease, non familial idiopathic dilated cardiomyopathy, age-related macular degeneration, non alcoholic fatty liver disease, diabetic neuropathy, various cancers such as breast, prostate, stomach, colon, lung and skin cancer [22-29]. The SOD2 polymorphism, however, has been generally studied in relation to DM and its associated complications [29-32].

Previous studies have shown that different polymorphisms from various SOD isoforms can be associated with vitiligo. Additionally, there have also been studies evaluating the expression and enzyme activity of SOD isoforms, in both blood and tissue. Many of these studies have produced conflicting outcomes, especially concerning the peripheral blood samples of vitiligo patients.

Picardo et al. [33] showed that blood levels of SOD were not significantly different in vitiligo patients, thus indicating that the melanocyte damage seen in vitiligo was not linked to generalized oxidative stress. In contrast, Laddha et al. [34] reported that increased activity of SOD2 and SOD3 due to polymorphisms may be genetic risk factors leading to susceptibility and progression of vitiligo. Hence, suggesting that the genetic make-up of an individual may form a basis for the effective treatment of the disease. In the studies related to SOD expression, both vitiliginous and non vitiliginous skin of patients showed a significant increase in the isoforms of SOD $[35,36]$. Because the same polymorphism could not be determined in all patients, the idea that the antioxidant system, in conjunction with various other pathways, plays a role in the disease's pathogenesis is well supported.

One of the limitations of this study was our inability to exactly measure the enzyme activities of SOD1 and SOD2 genes. It would have been useful to highlight the effects of polymorphisms studied, and correlate the genotyping data. Consequently, this study needs to be substantiated by future studies containing larger patient numbers.

\section{REFERENCES}

1. Alikhan A, Felsten LM, Daly M, Petronic-Rosic V. Vitiligo: A comprehensive overview. J Am Acad Dermatol. 2011; 65(3): 473-491.

2. Kovacs SO. Vitiligo. J Am Acad Dermatol. 1998; 38(5): 647-666.

3. Kemp EH, Waterman EA, Weetman AP. Immunological pathomechanisms in vitiligo. Expert Rev Mol Med. 2001; 3(20): 1-22. 
4. Westerhof W, D'Ischia M. Vitiligo puzzle: The pieces fall in place. Pigment Cell Res. 2007; 20(5): 345-359.

5. Ben Ahmed M, Zaraa I, Rekik R, Elbeldi-Ferchiou A, Kourda N, Belhadj Hmida N, et al. Functional defects of peripheral regulatory $\mathrm{T}$ lymphocytes in patients with progressive vitiligo. Pigment Cell Melanoma Res. 2011; 25(1): 99-109.

6. Ongenae K, Geel NV, Naeyaert JM. Evidence for an autoimmune pathogenesis of vitiligo. Pigment Cell Res. 2003; 16(2); 90-100.

7. Hazneci E, Karabulut AB, Oztürk C, Batçioğlu K, Doğan G, Karaca S, et al. A comparative study of superoxide dismutase, catalase and glutathione peroxidase activities and nitrate levels in vitiligo patients. Int J Dematol. 2005; 44(8): 636-640.

8. Khan R, Satyam A, Gupta S, Sharma VK, Sharma A. Circulatory levels of antioxidans and lipid peroxidation in Indian patients with generalized and localized vitiligo. Arc Dermatol Res. 2009; 301(10): 731-737.

9. Dammak I, Boudaya S, Abdallah FB, Hamida T, Attia H. Antioxidant enzymes and lipid peroxidation at the tissue level in patients with stable and active vitiligo. Int J Dermatol. 2009; 48(5): 476-480.

10. Yildirim M, Baysal V, Inaloz HS, Can M. The role of oxidants and antioxidants in generalized vitiligo at tissue level. J Eur Acad Dermatol Venereol. 2004; 18(6): 683-686.

11. Boisseau-Garsaud AM, Garsaud P, Lejoly-Boisseau H, Robert M, Quist D, Arveiler B. Increase in total blood antioxidant status and selenium levels in black patients with active vitiligo. Int J Dermatol. 2002; 41(10): 640-642.

12. Agarwal D, Shajil EM, Marfatia YS, Begum R. Study on the antioxidant status of vitiligo patients of different age groups in Baroda. Pigment Cell Res. 2004; 17(3): 289-294.

13. Kinnula VL, Pakko P, Soini Y. Antioxidant enzymes and redox regulating thiol proteins in malignancies of human lung. FEBS Lett. 2004; 569(1-3): 1-6.

14. Kinnula VL, Crapo JD. Superoxide dismutases in malignant cells and human tumors. Free Radic Biol Med. 2004; 36(6): 718-744.

15. Deng HX, Hentati A, Tainer JA, Iqbal Z, Cayabyab A, Hung WY, et al. Amyotrophic lateral sclerosis and structural defects in $\mathrm{Cu}, \mathrm{Zn}$ superoxide dismutase. Science. 1993; 261(5124): 1047-1051.

16. Mancuso ML, Filosto M, Naini A, Rocchi A, Del Corona A, Sartucci F, et al. A screening for superoxide dismutase-1 D90A mutation in Italian patients with sporadic amyotrophic lateral sclerosis. Amyotroph Lateral Scler Other Motor Neuron Disord. 2002; 3(4): 215-218.

17. Zhang Y, Zhang L, Sun D, Li Z, Wang L, Liu P. Genetic polymorphisms of superoxide dismutases, catalase and glutathione peroxidase in age-related cataract. Mol Vis. 2011; 17: 2325-2332.

18. Nordberg J, Arner ESJ. Reactive oxygen species, antioxidants and the mammalian thioredoxin system. Free Radic Biol Med. 2001; 31(11): 1287-1317.

19. Valko M, Leibfritz D, Moncol J, Cronin MT, Mazur M, Telser J. Free radicals and antioxidants in normal physiological functions and human disease. Int J Biochem Cell Biol. 2007; 39(1); 44-84.

20. Passi S, Grandinetti M, Maggio F, Stancato A, De Luca C. Epidermal oxidative stress in vitiligo. Pigment Cell Res. 1998; 11(2): 81-85.

21. Sutton A, Khoury H, Prip-Buus C, Cepanec C, Pessayre D, Degoul F. The Ala16Val genetic dimorphism modulates the import of human manganese superoxide dismutase into rat liver mitochondria. Pharmacogenetics. 2003; 13(3): 145-157.

22. Kimura K, Isashiki Y, Sonoda S, Kakiuchi-Matsumoto $\mathrm{T}$, Ohba N. Genetic association of manganase superoxide dismutase with exudative age-related macular degeneration. Am J Ophthalmol. 2000; 130(6): 769773.

23. Han J, Colditz GA, Hunter DJ. Manganese superoxide dismutase polymorphism and risk of skin cancer. Cancer Causes Control. 2007; 18(1): 79-89.

24. Wang LI, Miller DP, Sai Y, Liu G, Su L, Wain JC, et al. Manganese superoxide dismutase alanine-tovaline polymorphism at codon 16 and lung cancer risk. J Natl Cancer Inst. 2001; 93(23): 1818-1821.

25. Dalan AB, Ergen A, Yilmaz H, Karateke A, Isbir T. Manganese superoxide dismutase gene polymorphism, MnSOD plasma levels and risk of epithelial ovarian cancer. J Obstet Gynaecol Res. 2008; 34(5): 878-884.

26. Liwei L, Chunyu L, Ruifa H. Association between manganese superoxide dismutase gene polymorphism and risk of prostate cancer: A meta-analysis. Urology. 2009; 74(4): 884-888.

27. Iguchi T, Wang CY, Delongchamps NB, Sunheimer R, Nakatani T, de la Roza G, et al. Association of prostate cancer and manganese superoxide dismutase AA genotype influenced by presence of occult cancer in control group. Urology. 2008; 72(2): 238-241. 
28. Tugcu V, Ozbek E, Aras B, Arisan S, Caskurlu T, Tasci AI. Manganese superoxide dismutase (MnSOD) gene polymorphism in urolithiasis. Urol Res. 2007; 35(5): 219-224.

29. Chistyakov DA, Savost'anov KV, Zotova EV, Nosikov VV. Polymorphisms in the Mn-SOD and EC-SOD genes and their relationship to diabetic neuropathy in type 1 diabetes mellitus. BMC Med Genet. 2001; 2: 4.

30. Lee SJ, Choi MG. Association of manganese superoxide dismutase gene polymorphism (V16A) with diabetic macular edema in Korean type 2 diabetic patients. Metabolism. 2006; 55(12): 1681-1688.

31. Lee SJ, Choi MG. Manganese superoxide dismutase gene polymorphism (V16A) is associated with stages of albuminuria in Korean type 2 diabetic patients. Metabolism. 2006; 55(1): 1-7.

32. Möllsten A, Marklund SL, Wessman M, Svensson M, Forsblom C, Parkkonen M, et al. A functional polymorphism in the manganese superoxide dismutase gene and diabetic nephropathy. Diabetes. 2007; 56(1): 265-269.
33. Picardo M, Passi S, Morrone A, Grandinetti M, Di Carlo A, Ippolito F. Antioxidant status in the blood of patients with active vitiligo. Pigment Cell Res. 1994; $7(2): 110-115$.

34. Laddha NC, Dwivedi M, Gani AR, Shajil EM, Begum $\mathrm{R}$. Involvement of superoxide dismutase isoenzymes and their genetic variants in progression of and higher susceptibility to vitiligo. Free Radic Biol Med. 2013; 65: 1110-1125.

35. Sravani PV, Babu NK, Gopal KV, Rao GR, Rao AR, Moorthy B, et al. Determination of oxidative stress in vitiligo by measuring superoxide dismutase and catalase levels in vitiliginous and non-vitiliginous skin. Indian J Dermatol Venereol Leprol. 2009; 75(3): 268-271.

36. Briganti S, Caron-Schreinemachers AL, Picardo M, Westerhof W. Anti-oxidant defence mechanism in vitiliginous skin increases with skin type. J Eur Acad Dermatol Venereol. 2012; 26(10): 1212-1219. 